\title{
The sorption of lysozyme and ribonuclease onto ferromagnetic nickel powder 2. Desorption and competitive adsorption
}

\author{
Hwai-Shen Liu *, Yu-Chi Wang \\ Department of Chemical Engineering, National Taiwan Unitersity. Taipei. Taiwan, Republic of China \\ Received 8 November 1994; accepted 30 January 1995
}

\begin{abstract}
The partial desorption of lysozyme or ribonuclease (RNase) from nickel powder was attained by $\mathrm{pH}$ switch and ion addition. and was found to decrease with adsorption time. Desorption by dilution was found to be insignificant. In the simultaneous competitive adsorption of these two proteins, selective adsorption could be achieved by controlling the $\mathrm{pH}$. As for sequential adsorption, R Nase-covered Ni can further adsorb lysozyme, but R Nase removed lysozyme from lysozyme-Ni.
\end{abstract}

Keywords: Competitive adsorption; Desorption; Ferromagnetic nickel powder; Lysozyme; Ribonuclease

\section{Introduction}

A complete separation process should include adsorption and desorption. Articles on protein desorption are not as frequent as those on adsorption. Methods of protein desorption often mentioned are dilution, $\mathrm{pH}$ switch, and the addition of an electrolyte or a displacer.

Lee and Ruckenstein [1] suggested that adsorbates could be classified as two types - a strongly bonding ( $\mathrm{SB}$ ) layer dependent on the interaction between the protein and the surface, and a loosely bonding ( $\mathrm{LB}$ ) layer. They concluded that dilution could only induce desorption of the LB layer because of the weaker attraction between the LB layer and the interface, and the repulsion between the LB layer and the SB layer. However, the results of experiments by Norde et al. [2] indicated that

\footnotetext{
* Corresponding author.
}

human plasma albumin (HPA) could not be desorbed from a silver iodide or silica surface by dilution, $\mathrm{pH}$ change, or ion addition, although it could be desorbed from a polyoxymethylene surface by a $\mathrm{pH}$ switch and a change in ionic strength. With hematite as the adsorbent, a change in $\mathrm{pH}$ could achieve a high degree of HPA desorption, as could the addition of ions. Cohen et al. [3] successfully applied morfoline as a displacer to desorb protein completely from a silica surface. Other articles on protein desorption can be found in the literature $[4 \cdots 6]$.

When a solid material makes contact with blood, bodily fluids, and other biological systems, proteins usually adsorb at the solid liquid interface. These proteins may compete for adsorption at any interface in the system. Initially, the interface will be covered by those protein molecules with the highest rate of arrival (i.e. the smallest and most abundant ones) [7]. During the later stages, the adsorbed molecules may be displaced by other molecules 
with a stronger tendency to adsorb. The final composition of the adsorbed layer at the interface is determined by the concentrations and types of proteins in the solution, the affinity of each protein, and the ability of each protein to adsorb [6]. Several investigators have tried to relate the blood compatibility of materials to the nature and the conformation of proteins at the interface $[8,9]$. A few experiments on competitive protein adsorption at the solid-liquid interface $[10,11]$ and an in situ investigation at the solution-air interface [12] have been reported. Proteins usually subjected to investigation are albumin (A), $\gamma$-globulin $(\mathrm{G})$, and fibrinogen $(\mathrm{F})$.

Moyer and Gorin [13] studied the competitive adsorption behavior of $A$ and $G$ on the surface of quartz and colloid particles more than five decades ago. Their results indicated that proteins hardly adsorbed onto each other when the adsorbent surface was covered by one protein and then exposed to the other, although one protein might be replaced by another. Usually, hydrophilic proteins adsorbed more readily onto a hydrophilic surface. Lee and $\mathrm{Kim}$ [14] showed that ${ }^{125}$ I-labeled $A, G$, and $F$ would adsorb competitively onto hydrophobic polymers. They noted that the adsorption of each protein from a mixed-protein solution was less than that observed with a singleprotein solution. Kochwa et al. [15] investigated both the sequential and simultaneous adsorption of proteins $A, G$, and $F$ to determine preferential binding to artificial surfaces. Their results revealed that on a polyurethane surface pre-adsorbed with unlabeled protein and then exposed to labeled protein, $G$ blocked the sequential adsorption of labeled $\mathrm{A}$ by $27 \%$, and $\mathrm{A}$ blocked that of labeled $\mathrm{G}$ by $46 \%$.

The competitive and sequential adsorption of milk proteins $\beta$-lactoglobumin and $\kappa$-casein on to both hydrophobic and hydrophilic surfaces was studied by Arnebrant and Nylander [16]. These two proteins have similar molecular weights (18000-19000), but $\beta$-lactoglobulin is a compact protein while $\kappa$-casein is a soft one. The results of the sequential adsorption experiments showed that adsorption of $\kappa$-casein occurred after pre-coating the surface with $\beta$-lactoglobumin, whereas additional adsorption of $\beta$-lactoglobulin did not take place after the pre-adsorption of $\kappa$-casein. When the proteins were added simultaneously, $\kappa$-casein adsorbed preferentially with a fraction of $\beta$-lactoglobulin that increased with increasing surface hyrophobicity.

As for the measurement of the concentration of proteins in a protein-mixture solution, the radiolabeling method $\left({ }^{125} \mathrm{I}\right)$ or the fluorescence technique was frequently used to determine the individual concentration in the solution. However, recent studies $[17,18]$ have revealed that the adsorption behavior of radiolabeled proteins onto a surface differs from that of unlabeled proteins, which may lead to misinterpretation because of a possible change in their physical properties. With Fourier transform-infrared (FT-IR) spectroscopy, problems still exist in quantifying the adsorbed proteins [19a]. Therefore, it is thought that the only reliable technique for quantification of the competitive adsorption of proteins onto the solid-liquid surface is the measurement of protein depletion in a solution by high performance liquid chromatography (HPLC).

In this companion article to our previous one [19b], we report on the desorption of single proteins, i.e. lysozyme and ribonuclease (RNase), from ferromagnetic powder nickel $(\mathrm{Ni})$ by dilution, $\mathrm{pH}$ switch, and anion addition, and the effect of preadsorption time. Further, the adsorption of mixtures of these two proteins, both simultaneously and sequentially, is investigated to determine the role of hydrophobicity, conformational stability, and electrical charge in the sorption process. The properties of these two proteins and the significance of $\mathrm{Ni}$ as an adsorbent were discussed in the previous article $[19 \mathrm{~b}]$.

\section{Materials and methods}

\subsection{Protein desorption}

Appropriate amounts of protein were dissolved in $10 \mathrm{ml} 0.005 \mathrm{M}$ buffer solutions, in polypropylene bottles, at $\mathrm{pH} 11$ for lysozyme and $\mathrm{pH} 8$ for RNase $\mathrm{Ni}$ powder was added to each bottle, which was then shaken at 250 r.p.m. for $60 \mathrm{~min}$ preadsorption. The protein concentration in each solution was measured to calculate the adsorbed 
amount. The drained protein-Ni complex was washed with a buffer solution several times to remove the free protein for later desorption experiments. Fresh buffer solutions of varying $\mathrm{pH}$, containing different types and concentrations of anions, were then added to the protein-Ni complex, and the concentrations of desorbed protein monitored as a function of time. To determine possible irreversible changes during the adsorption process, the pre-adsorption times were set at 20 , 35 , and $50 \mathrm{~min}$.

\subsection{Adsorption kinetics curve of the protein mixture}

\section{Simultaneous competitive adsorption}

A mixture of lysozyme and RNase with an adjusted $\mathrm{pH}$ of 7.8 or 11 was added to $0.15 \mathrm{~g} \mathrm{Ni}$ powder and shaken at 250 r.p.m. The respective amounts of protein adsorbed were obtained from the difference between the initial and final concentrations of both lysozyme and RNase in the solution at various time periods by HPLC.

\section{Sequential adsorption}

An R Nase solution of $\mathrm{pH} 8.0$ was pre-adsorbed onto $0.15 \mathrm{~g} \mathrm{Ni}$ powder for $60 \mathrm{~min}$. The drained and washed RNase-Ni complex was added to a lysozyme solution of $\mathrm{pH} 11$. The sequentially adsorbed amount of lysozyme and the desorbed amount of RNase were measured using the difference between the initial and final concentrations of lysozyme and RNase for various time periods by HPLC. The experimental steps of lysozyme preadsorption and RNase sequential adsorption were similar, but were in reverse order.

\subsection{Analysis of protein concentration}

The individual concentration was measured with UV $280 \mathrm{~nm}$, while the concentrations in the protein mixture were analyzed by HPLC (Perkin Elmer LC $-235 \mathrm{C}$ ). The HPLC apparatus was equipped with a Perkin Elmer mode 250 biocompatible binary LC pump, a diode array detector, and a PE Nelson 1020 LC plus integrator. A Supelcosil LC-3DP wide pore column, $5 \mathrm{~g}$ packing, $5 \mathrm{~cm} \times$ $4.6 \mathrm{~mm}$ i.d. with $1 \mathrm{ml} / \mathrm{min}^{-1}$ mobile phase, was used. The composition of the mobile phase was operated at a linear gradient from $95 \%$ A with
$5 \% \mathrm{~B}$ to $40 \%$ A with $60 \% \mathrm{~B}$ within $15 \mathrm{~min}$, where A represents a mixture of $10 \%$ isopropanol and $90 \%$ trifluoroacetic acid $(0.1 \%, \mathrm{pH} 2.1)$ and $\mathrm{B}$ a mixture of $90 \%$ isopropanol and $10 \%$ trifluoroacetic acid $(0.1 \%, \mathrm{pH} 2.1)$. The injection volume was $20 \mu \mathrm{l}$. The retention times for lysozyme and RNase were 9.8 and $7.3 \mathrm{~min}$, respectively.

\section{Results and discussion}

\subsection{Effects of $p H$ and anions on desorption}

The effects of $\mathrm{pH}$ and anions on the lysozyme desorption kinetics curves are shown in Fig. 1(A) (salt-free), 1(B) $(0.1 \mathrm{M} \mathrm{NaCl})$ and 1 (C) $(0.1 \mathrm{M}$ $\mathrm{NaSCN}$ ); those on the RNase curves are shown in Fig. 2(A) (salt-free), 2(B) (0.1 M NaCl) and 2(C) (0.1 M NaSCN). As can be seen, it took about $20 \mathrm{~h}$ for RNase and $40 \mathrm{~h}$ for lysozyme to reach desorption equilibrium a much longer time than for adsorption. Because R Nase has more charged groups on its surface [20], there was a stronger repulsion between $\mathrm{Ni}$ and protein, as well as between protein and protein, when the $\mathrm{pH}$ departed from the IEP. However, lysozyme is a hydrophobic protein, and thus the desorption rate was slower.

The desorption fraction can be defined as the ratio of actual desorbed amount to the ideal maximal protein desorbed amount, which means that the final equilibrium condition lies on the adsorption isotherm. The desorption fraction of lysozyme and RNase obtained from the previous Figures is listed in Tables 1(A) (lysozyme) and 1(B) (RNase). Table 1(A) shows that although electrostatic repulsion occurred between lysozyme and the Ni surface at pH 5 and 12, the desorbed fraction at pH 12 was higher than that at $\mathrm{pH} 5$. If the extended degree of protein conformation is symmetric to IEP [21]. lysozyme has a more denatured conformation and more hydrophobic interactions occur among the lysozyme molecules at $\mathrm{pH} 5$. This would result in a higher desorption fraction at $\mathrm{pH} 12$ than at pH 5. As for the ionic effect of electrolytes ( $\mathrm{NaCl}$. NaSCN) shown in Figs. 1(B), and 1(C) for lysozyme, and Figs. 2(B) and $2(C)$ for R Nase, the desorption fraction was increased, particularly for NaSCN. From the lyotropic series defined by 

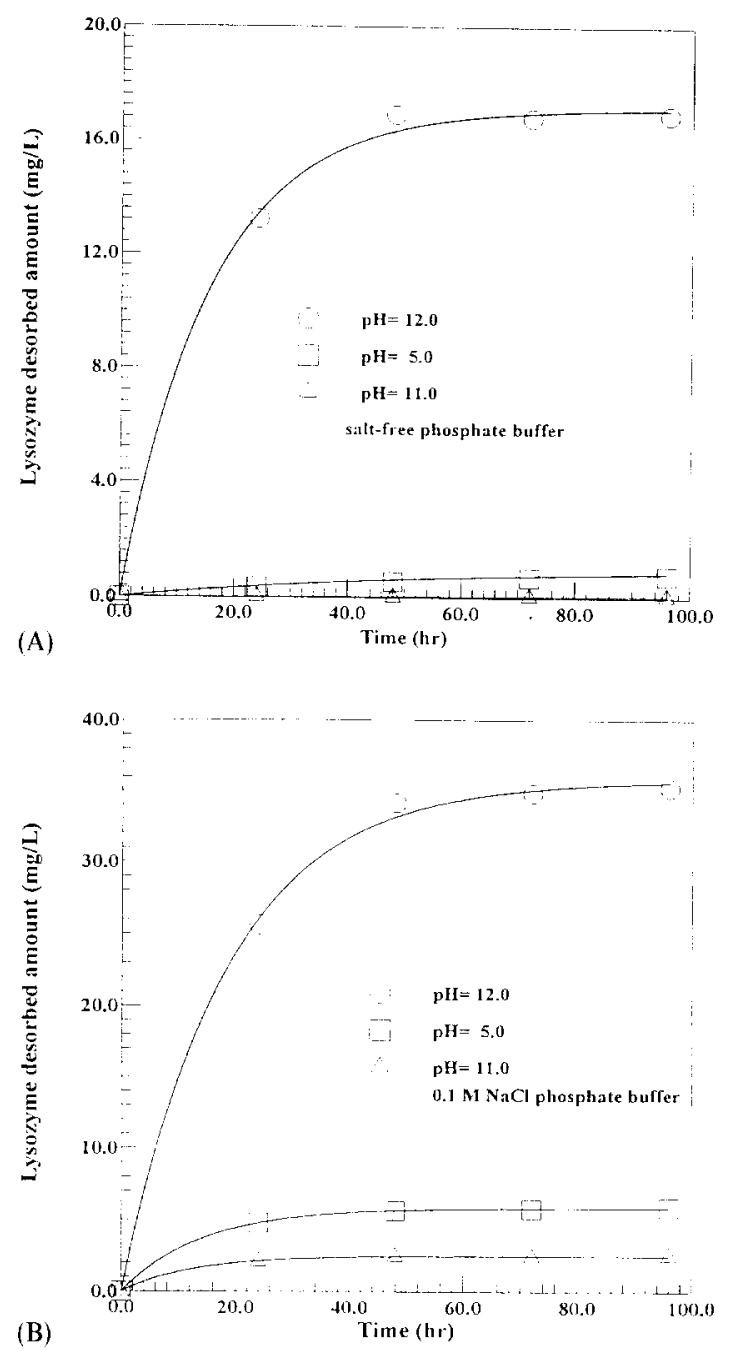

(B)

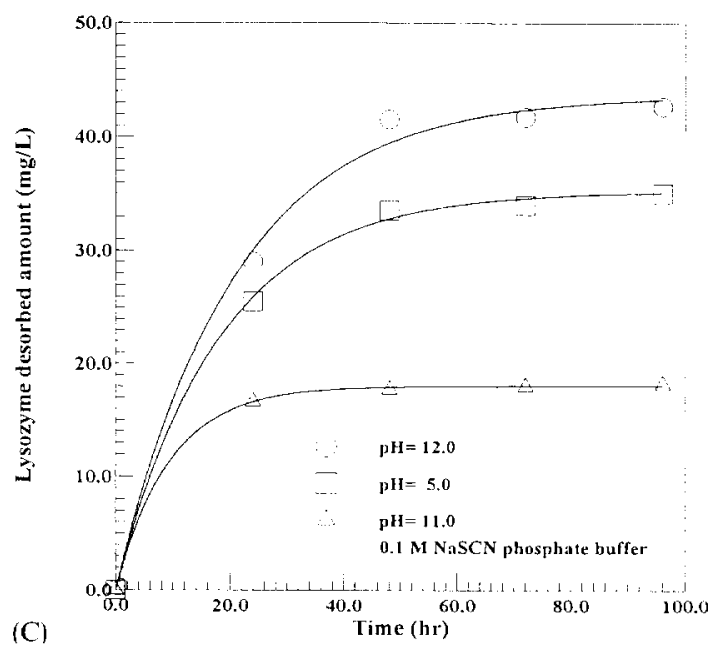

Porath [22], $\mathrm{SCN}^{-}$is a chaotropic anion, which could enhance protein desorption. Moreover, the surface charge groups could be significantly suppressed by $\mathrm{SCN}^{-}$, which was confirmed from the electrophoretic mobilities of bare Ni powder in the companion article [19b]. RNase has a comparable extent of unfolding and an absolute surface charge for $\mathrm{pH} 5$ and 12 as its IEP is around $\mathrm{pH} 8$. Because the IEP of $\mathrm{Ni}$ is about $\mathrm{pH} 9.5-10$ [23], the repulsive force between $\mathrm{Ni}$ and protein at $\mathrm{pH} 5$ was stronger than that at $\mathrm{pH} \mathrm{12,} \mathrm{and} \mathrm{the} \mathrm{desorption}$ fraction at $\mathrm{pH} 5$ was higher than that at $\mathrm{pH} 12$, as indicated in Table $1(\mathrm{~B})$. The results for $\mathrm{RNase}$ desorption with the addition of $\mathrm{NaCl}$ and $\mathrm{NaSCN}$ were quite similar to those for lysozyme.

\subsection{Effect of pre-adsorption time on protein desorption}

The lysozyme desorption fraction at $\mathrm{pH} 11$ and the RNase desorption fraction at $\mathrm{pH} 8$ as a function of pre-adsorption time are shown in Table 2. It can be seen in both cases that the desorption fraction was reduced drastically when the preadsorption time was gradually increased. This might have been due to some irreversible conformational rearrangement and to interactions during the adsorption process, which were monitored by FT-IR/ATR in the companion article [19b]. It can also be seen that the desorption fraction increased with the amount adsorbed, which is consistent with the hypothesis of Lee and Ruckenstein [1] that a protein in the LB layer is easily desorbed owing to its weak attractive force.

\subsection{Adsorption kinetics curve of the lysozyme and RNase mixture}

Simultaneous competitive adsorption and sequential adsorption for protein mixtures were studied for a better understanding of the inter-

Fig. 1. Time dependence of lysozyme desorption. Conditions: volume, $10 \mathrm{~m}$; $\mathrm{Ni}, 0.2 \mathrm{~g}$; original adsorbed amount, $2.5 \mathrm{mg}$ per $\mathrm{g}$ of $\mathrm{Ni}$ at $\mathrm{pH}$ 11. (A) Desorption in salt-free phosphate buffer. (B) Desorption in 0.1 M NaCl phosphate buffer. (C) Desorption in $0.1 \mathrm{M} \mathrm{NaSCN}$ phosphate buffer. 

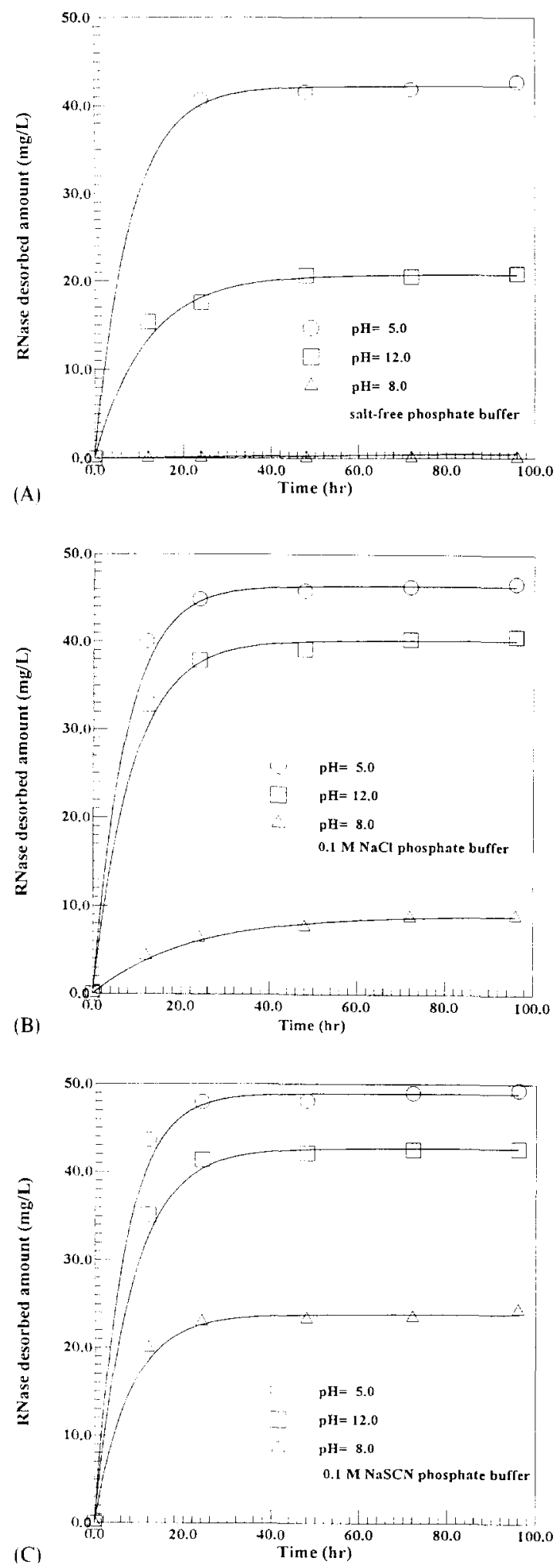

Table 1

The desorption fraction of lysozyme and R Nase for various $\mathrm{pH}$ values and anions

(A) Pre-adsorbed lysozbme: $2.5 \mathrm{mg}$ per $\mathrm{g}$ of $\mathrm{Ni}$

\begin{tabular}{lrl}
\hline & $\mathrm{pH}$ & $\begin{array}{l}\text { Desorption } \\
\text { fraction }\end{array}$ \\
\hline (1) Salt-free phosphate buffer & 5.0 & 0.016 \\
& 11.0 & 0.001 \\
& 12.0 & 0.40 \\
(2) $1 \mathrm{M} \mathrm{NaCl}$ phosphate buffer & 5.0 & 0.118 \\
& 11.0 & 0.05 \\
& 12.0 & 0.704 \\
& 5.0 & 0.701 \\
& 11.0 & 0.363 \\
& 12.0 & 0.854 \\
\hline
\end{tabular}

(B) Pre-adsorbed RNase: $2.4 \mathrm{mg}$ per $\mathrm{g}$ of $\mathrm{Ni}$

\begin{tabular}{lrl} 
& pH & $\begin{array}{c}\text { Desorption } \\
\text { fraction }\end{array}$ \\
\hline (1) Salt-free phosphate buffer & 5.0 & 0.852 \\
& 8.0 & 0.001 \\
& 12.0 & 0.416 \\
(2) $0.1 \mathrm{M} \mathrm{NaCl}$ phosphate buffer & 5.0 & 0.956 \\
& 8.0 & 0.182 \\
& 12.0 & 0.812 \\
& 5.0 & 0.987 \\
& 8.0 & 0.502 \\
& 12.0 & 0.852 \\
\hline
\end{tabular}

actions among lysozyme, RNase and $\mathrm{Ni}$, as well as for comparison with individual proteins.

\section{Simultaneous competitive adsorption}

A simultaneous competitive adsorption of this mixture is shown in Figs. 3(A) $(\mathrm{pH} 8)$ and $3(\mathrm{~B})$ $(\mathrm{pH} 11)$. An "overshoot", possibly caused by a relaxation or arrangement of the adsorbed layer, was also observed. It was found that the amount of lysozyme adsorbed (about $0.45 \mathrm{mg}$ per $\mathrm{g}$ of $\mathrm{Ni}$ ) was similar at the same initial concentration for

Fig. 2. Time dependence of RNase desorption. Conditions: volume, $10 \mathrm{ml}$; $\mathrm{Ni}, 0.2 \mathrm{~g}$; original adsorbed amount, $2.4 \mathrm{mg}$ per $\mathrm{g}$ of $\mathrm{Ni}$ at $\mathrm{pH}$ 8. (A) Desorption in salt-free phosphate buffer. (B) Desorption in $0.1 \mathrm{M} \mathrm{NaCl}$ phosphate buffer. (C) Desorption in $0.1 \mathrm{M}$ NaSCN phosphate buffer. 
Table 2

The desorption fraction of lysozyme and $\mathrm{R}$ Nase for various pre-adsorption times

(A) Pre-adsorbed lysozyme

\begin{tabular}{lll}
\hline $\begin{array}{l}\text { Amount of lysozyme } \\
\text { (mg per g of Ni) }\end{array}$ & $\begin{array}{l}\text { Pre-adsorption } \\
\text { time (min) }\end{array}$ & $\begin{array}{l}\text { Desorption } \\
\text { fraction }\end{array}$ \\
\hline 1.9 & 20 & 0.863 \\
& 35 & 0.162 \\
& 50 & 0.014 \\
4.5 & 20 & 0.923 \\
& 35 & 0.451 \\
& 50 & 0.048 \\
\hline
\end{tabular}

(B) Pre-adsorbed RNase

\begin{tabular}{lll}
\hline $\begin{array}{l}\text { Amount of RNase } \\
\text { (mg per g of Ni) }\end{array}$ & $\begin{array}{l}\text { Pre-adsorption } \\
\text { time (min) }\end{array}$ & $\begin{array}{l}\text { Desorption } \\
\text { fraction }\end{array}$ \\
\hline 2.0 & 20 & 0.837 \\
& 35 & 0.103 \\
& 50 & 0.012 \\
4.5 & 20 & 0.918 \\
& 35 & 0.461 \\
& 50 & 0.052 \\
\hline
\end{tabular}

both $\mathrm{pH} 8.0$ and 11. This was not true for RNase, however, the reason possibly being that R Nase is a more hydrophilic protein and has more charged groups on its surface, whereas lysozyme is a more hydrophobic protein. Therefore, the effect of the change in $\mathrm{pH}$ was more profound for RNase. Results from competitive adsorption in Figs. 3(A) and $3(\mathrm{~B})$ also indicated that the adsorbed amount of each protein in the mixture solution was lower than that of the single protein. When the $\mathrm{pH}$ value is 8.0 , roughly equal to the IEP of RNase, the electrostatic repulsion between $\mathrm{Ni}-\mathrm{RNase}$ and RNase-RNase is weakest, but both lysozyme and Ni carry positive surface charges, which leads to a decreased adsorption of lysozyme. Moreover, the hydrophobic interaction of lysozyme-lysozyme and lysozyme-R Nase cannot be ignored, subjecting lysozyme adsorption to an unfavorable environment as discussed in Ref. [24]. Also shown in Fig. 3(B) for pH 11 (roughly equal to the IEP of lysozyme), lysozyme can adsorb rapidly onto the $\mathrm{Ni}$ surface, and the adsorbed amount of RNase was initially very low because of the electrostatic

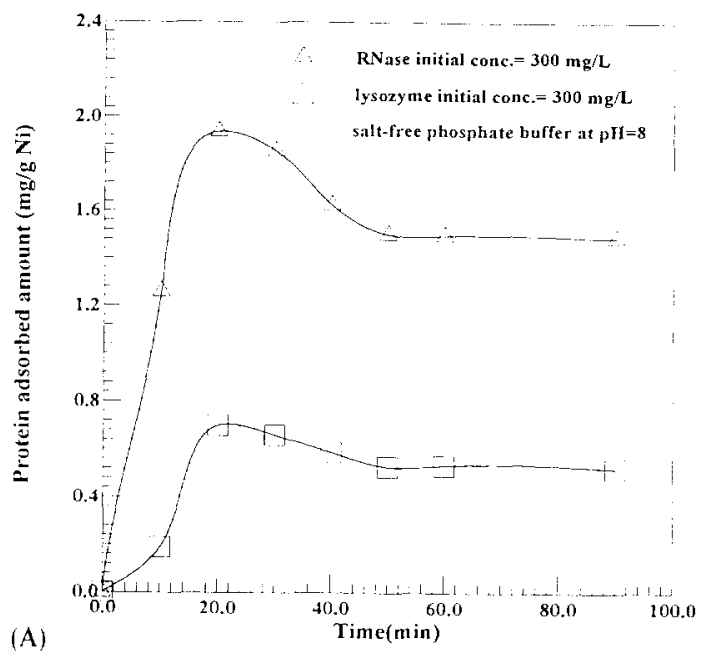

(A)

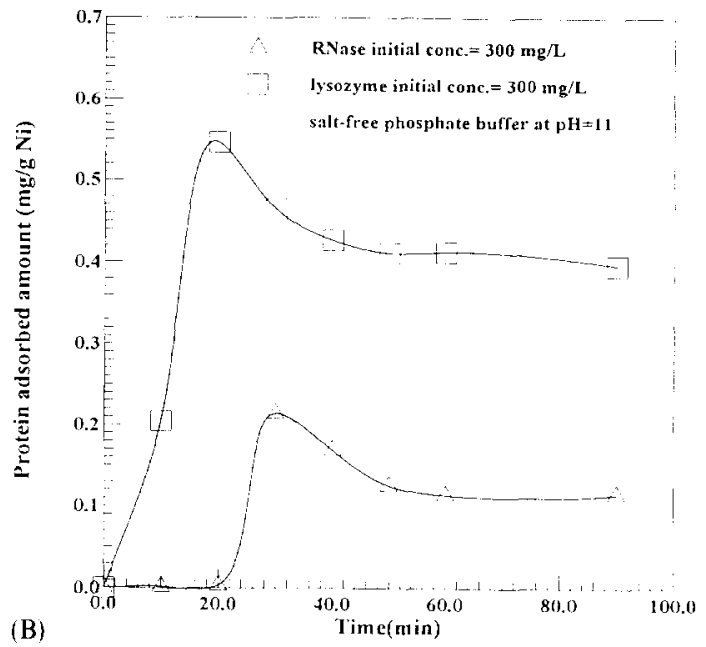

Fig. 3. Time dependence of simultaneous adsorption of the lysozyme and RNase mixture. Conditions: volume, $20 \mathrm{ml} ; \mathrm{Ni}$, 0.15 g. (A) Adsorption in $\mathrm{pH} 8$ phosphate buffer. (B) Adsorption in $\mathrm{pH} 11$ phosphate buffer.

repulsive force. With increasing time, the conformational change of RNase and the relaxation of the lysozyme adsorbed layer caused R Nase to be adsorbed and reached a plateau.

\section{Sequential adsorption}

In Fig. 4(A), the pre-adsorbed amount of RNase at $\mathrm{pH} 8.0$ was $2.5 \mathrm{mg}$ per $\mathrm{g}$ of $\mathrm{Ni}$, after which the $\mathrm{pH}$ value was switched to 11 for a continuous adsorption of lysozyme. It was observed that RNase 

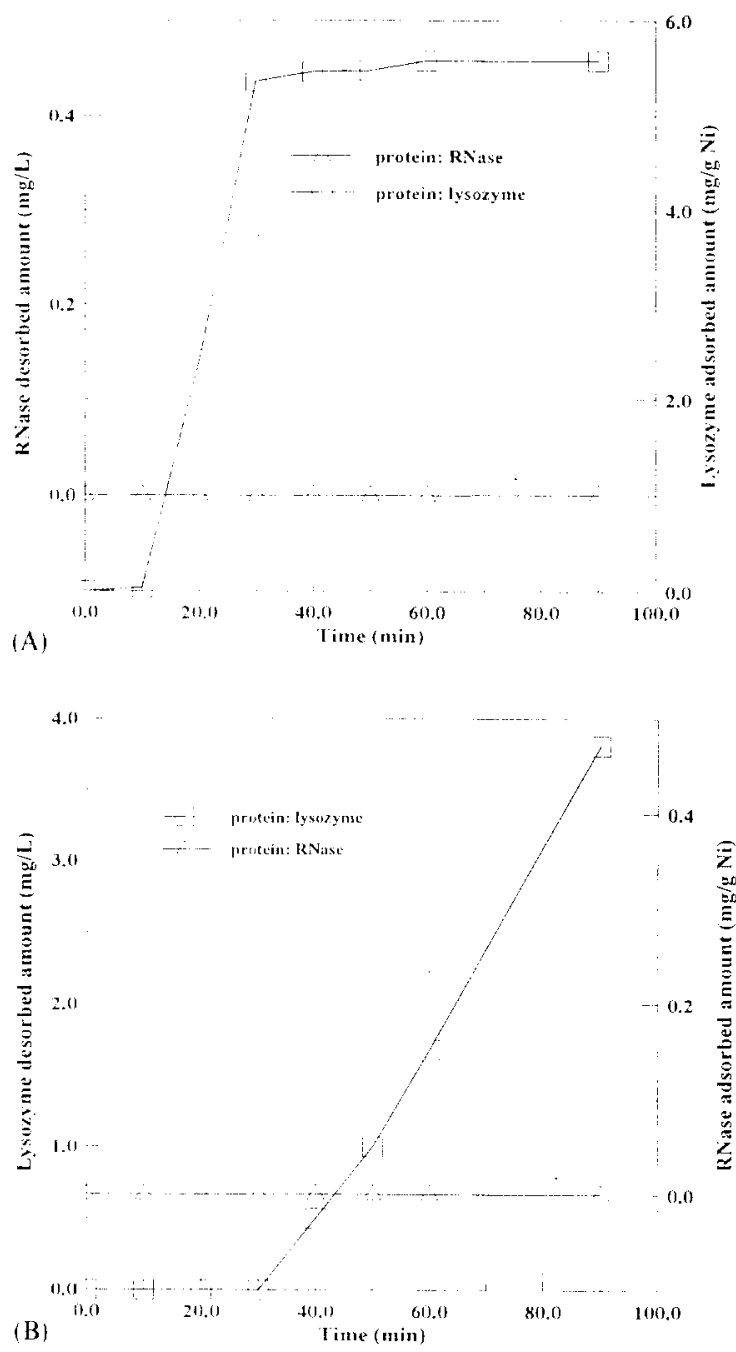

Fig. 4. Time dependence of sequential adsorption. Conditions: volume, $20 \mathrm{ml} ; \mathrm{Ni}, 0.15$. (A) RNase pre-adsorbed amount: $2.5 \mathrm{mg}$ per $\mathrm{g}$ of $\mathrm{Ni}$ at $\mathrm{pH} 8$ and then $\mathrm{pH} 11$ for lysozyme adsoprtion. (B) Lysozyme pre-adsorbed amount: $2.5 \mathrm{mg}$ per g of $\mathrm{Ni}$ at $\mathrm{pH} 11$ and then $\mathrm{pH} 8$ for RNase adsorption.

could not be displaced by lysozyme, but lysozyme could adsorb onto the RNase-adsorbed layer. This was because. on the Ni surface, structurally unstable RNase underwent some conformational extension and occupied more than one adsorbing site. This caused the strong interaction between the first adsorbed layer of R Nase and the Ni surface and, thus. RNase could not be replaced with lysozyme. When RNase was unfolded and the hydrophobic amino acids were exposed to the outside, lysozyme could be attracted by R Nase owing to hydrophobic interactions. With sequential adsorption in the reverse order, lysozyme was pre-absorbed onto $\mathrm{Ni}$ before the addition of the R Nase solution $(\mathrm{pH} 8)$. It can be seen from Fig. 4(B), R Nase did not easily adsorb onto the lysozyme-covered $\mathrm{Ni}$ surface, but lysozyme was removed by R Nase molecules. The interaction between hydrophobic lysozyme and hydrophilic Ni surface was weak. Therefore, addition of R Nase at pH 8.0 could induce lysozyme to leave the $\mathrm{Ni}$ surface.

\subsection{Adsorption isotherms of the lisozlme and RNase mixture}

The adsorption isotherms of the lysozyme and R Nase mixture at $\mathrm{pH} 11$ are shown in Fig. 5(A). It was found that the adsorbed amount of RNase reached a plateau after an equilibrium concentration of $400 \mathrm{mg}^{-1}$, while the adsorption of lysozyme increased rapidly. Fig. 5(A) can be explained by the hydrophobic interaction between lysozyme and unfolded R Nase molecules at $\mathrm{pH} \mathrm{11}$. as shown by previous simultaneous and sequential adsorption experiments. When the $\mathrm{pH}$ value was 8.0 , the adsorbed amount of RNase was lower than that of lysozyme in the initial stages. However, with increasing $\mathrm{R}$ Nase concentration and the affinity between $\mathrm{Ni}$ and RNase at $\mathrm{pH} 8.0$. the adsorbed amount of RNase increased gradually. and lysozyme left the Ni surface owing to the unsuitable surroundings. as shown in Fig. 5(B).

\section{Conclusion}

The results of desorption experiments indicated that dilution did not lead to significant desorption: however, a protein could be (partially) removed from the $\mathrm{Ni}$ surface by a change in $\mathrm{pH}$ from the IEP and by an increase in ionic strength, particularly for $\mathrm{SCN}^{-}$. The degree of protein desorption fell drastically with increasing pre-adsorption time.

From the simultaneous competitive adsorptions of the lysozyme and R Nase mixtures, it was found that selective adsorption could be achieved by controlling the $\mathrm{pH}$. In the sequential adsorption experiment. the RNase-covered $\mathrm{Ni}$ powder could further adsorb lysozyme, probably through hydro- 

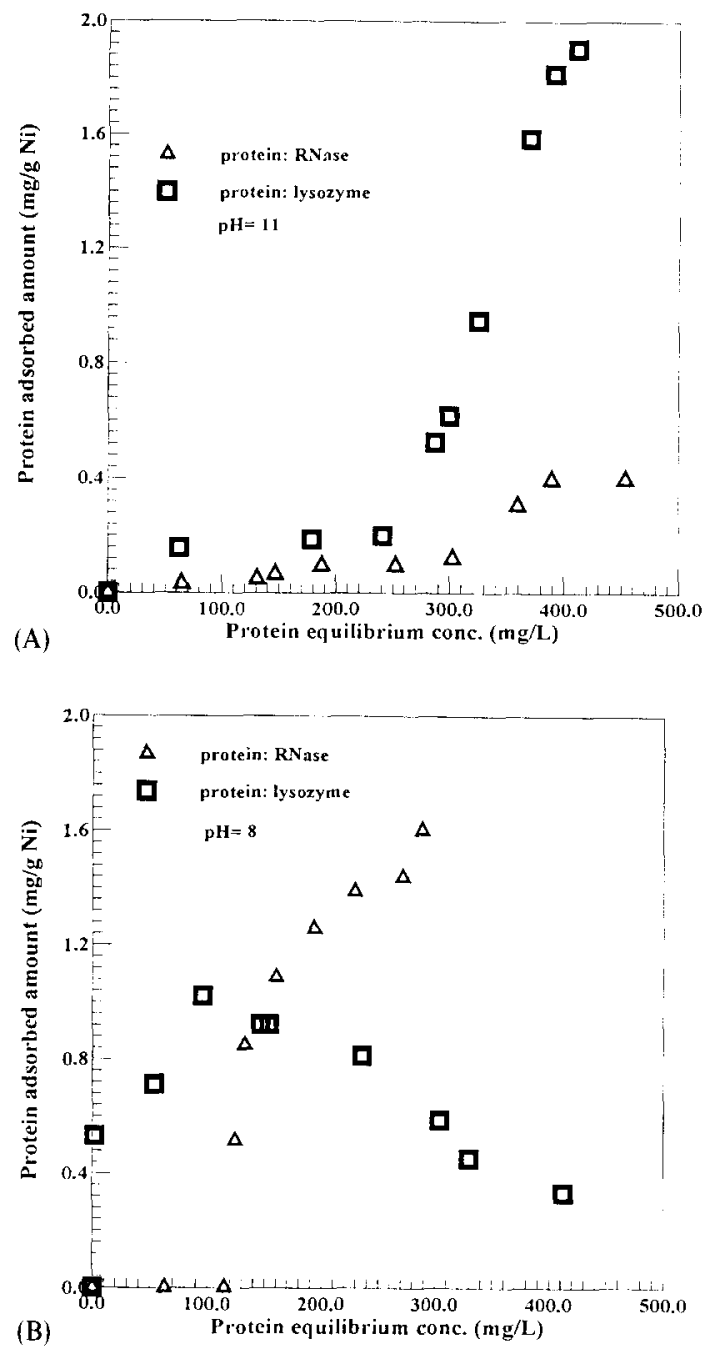

Fig. 5. Competitive adsorption isotherms of the lysozyme and RNase mixture: (A) Adsorption in $\mathrm{pH} 11$ phosphate buffer; (B) Adsorption in pH 8 phosphate buffer.

phobic interactions without RNase being desorbed from the $\mathrm{Ni}$ surface. When the lysozyme-covered Ni made contact with the RNase solution, RNase did not adsorb onto the sorbent surface, but preadsorbed lysozyme molecules detached from the surface to some extent. The development of the immobilization of enzymes, for instance, BSAcovered support, could adsorb chymotrypsin without any loss of enzyme activity [25]. Displacement of chromatogrphy may be based on the findings from the sequential adsorption.

\section{Acknowledgement}

The authors gratefully acknowledge the support of the National Science Council, Taiwan, Republic of China.

\section{References}

[1] S.H. Lee and E. Ruckenstein, J. Colloid Interface Sci., 125 (1988) 365.

[2] W. Norde, F. MacRitchic, G. Nowicka and J. Lyklema, J. Colloid Interface Sci., 112 (1986) 447.

[3] M.A. Cohen, G.I. Fleer and J.M.H.M. Scheutjens, J. Colloid Interface Sci., 97 (1984) 526.

[4] C.R. McMillin and A.G. Walton, J. Colloid Interface Sci., 48 (1974) 345 .

[5] R.L. Beissinger and E.F. Leonard, ASAIO, J., 3 (1980) 160.

[6] S.I. Stupp, J.W. Kauffman and S.H. Carr, J. Biomed. Mater. Res., 11 (1977) 237.

[7] T. Arai and W. Norde, Colloids Surfaces, 51 (1990) 17.

[8] J.L. Brash and D.J. Lyman, Chem. Biosurf., (1971) 177.

[9] F. MacRitchie, Adv. Protein Chem., 32 (1978) 283.

[10] T.A. Horbett and P.K. Wethersby, J. Biomed. Mater. Res., 15 (1981) 403.

[11] I.V. Ihlenfeld and S.L. Cooper, J. Biomed. Mater. Res., 13 (1979) 577.

[12] A. Blaskin and M.M. Boissonnade, J. Biomed. Mater. Res., 27 (1993) 145.

[13] L.S. Moyer and M.H. Gorin, J. Biol. Chem., 133 (1940) 605 .

[14] R.G. Lee and S.W. Kim, J. Biomed. Mater. Res., 8 (1974) 251 .

[15] S. Kochwa, R.S. Litwak and E.F. Leonard, N.Y. Ann, Acad. Sci., 283 (1977) 37.

[16] T. Arnebrant and T. Nylander, J. Colloid Interface Sci., $111(1986) 529$.

[17] H.G.W. Lensen, D. Bargeman, P. Bergveld and J. Feijen, J. Colloid Interface Sci., 99 (1984) 1.

[18] G. Desmet, D. Thomas and J.L. Boitieux, J. Chromatogr., 376 (1986) 199.

[19] (a) R.M. Gendreau, R.I. Leininger, S. Winters and R.B. Jakobsen, Adv. Chem. Ser., 199 (1982) 371.

(b) H.-S. Liu, Y.-C. Wang and W.-Y. Chen, Colloids Surfaces B: Biointerfaces, 5 (1995) 25.

[20] G.J. Fleer and J. Lyklema, Adsorption from Solution at the Solid-Liquid Interface, Academic Press, New York, 1983, pp. 153-220.

[21] A. Kondo, S. Oku and K. Higashitani, J. Colloid Interface Sci., 143 (1991) 214.

[22] J. Porath. Biotechnol. Prog., 3 (1987) 14.

[23] M.G. Weeks, P.A. Munro and P.L. Speeding, Biotech. Bioeng. 25 (1983) 699.

[24] K. Miyajima, Structure and Physical Property of Water, Nankodo, Tokyo, 1974, p. 90.

[25] P.J. Halling and P. Dunnill, Biotech. Bioeng., 21 (1979) 393. 